\title{
EPISTEMOLOGY OF RECONSTRUCTION OF PROPHETIC THINKING METHODOLOGY IN THE VIEW OF MUSA ASY'ARIE
}

\section{Zaprulkhan}

IAIN Syaikh Abdurrahman Siddik Bangka Belitung

zaprulkhan_zahra@yahoo.co.id

Abstract : Prophet Muhammad besides being a leader and statesman, he was also a great thinker. Aside from being a master educator, he was also a rational-transcendental thinker. But not many of us are able to see the Prophet Muhammad in the aspect of his thinking. In the perspective of Musa Asy'arie, the most important aspect for us to emulate in the Prophet Muhammad is his aspect of thought. When we are able to emulate the dimensions of the Prophet's thinking, we will be able to apply the method of prophetic thinking. This paper raises several epistemological questions: What is the meaning of prophetic thinking? How is the epistemology of reconstruction prophetic thinking in the perspective of Musa Asy'arie? This study uses philosophical and historical approach. It is found that in the view of Musa Asy'arie prophetic thinking is transcendental rational thinking by uniting between aspect rational and spiritual aspects. While the epistemology of prophetic thinking is a systemic integrative thinking process between transcendental awareness and scientific methodological and technological thinking in order to find God's laws that can produce knowledge, science and technology. This paper will elaborate epistemology of reconstruction of prophetic thinking metodology in the view of Musa Asy'arie.

Abstrak : Nabi Muhammad Saw di samping sebagai seorang pemimpin dan negarawan, beliau juga merupakan seorang pemikir besar. Selain sebagai seorang pendidik ulung, beliau juga merupakan seorang pemikir rasional-transendental. Namun tidak banyak di antara kita yang mampu melihat Nabi Muhammad Saw dalam aspek pemikirannya. Dalam 
perspektif Musa Asy'arie, aspek yang paling penting untuk kita teladani pada diri Nabi Muhammad Saw adalah aspek pemikirannya. Ketika kita mampu meneladani dimensi pemikiran Sang Nabi, maka kita akan mampu mengaplikasikan metode berpikir profetik. Tulisan ini mengajukan beberapa pertanyaan epistemologis: Apakah makna berpikir profetik? Bagaimana epistemologi rekonstruksi berpikir profetik dalam perspektif Musa Asy'arie? Kajian ini menggunakan pendekatan filosofis dan historis. Hasilnya ditemukan bahwa dalam pandangan Musa Asy'arie berpikir profetik adalah berpikir yang rasional transendental dengan menyatukan antara aspek rasional dan aspek spiritual. Sedangkan epistemologi berpikir profetik merupakan proses berpikir yang bersifat sistemik integratif antara kesadaran transendental dengan berpikir metodologis saintifik dan teknologi dalam rangka menemukan hukum-hukum Tuhan yang dapat menghasilkan ilmu pengerahuan, sains dan teknologi. Makalah ini akan mengelaborasi epistemologi rekonstruksi metodologi berpikir profetik dalam pandangan Musa Asy'arie.

Keywords : Epistemology, Reconstruction, Prophetic Thinking, Methodology, Musa Asy'arie

\section{A. Introduction}

If we are asked questions as Muslims: Who is our ideal example in this life? Of course, we will answer with confidence: our ideal example is the Prophet Muhammad. Because the normative foundation is clear:"Indeed, the Prophet himself has a good example for you, namely for those who always hope for the mercy of Allah and the happiness of the Hereafter, and a lot of remembrance to Allah" (Surah Al-Ahzab / 33:21).

But we can continue the question: What should we emulate from our human beings like the Prophet Muhammad? Normally we answer: that we must emulate all the greetings, attitudes and behavior. We must emulate the Prophet Muhammad in all aspects of his life. We must emulate the behavior of the Prophet Muhammad as a husband and father, as a leader and educator, as a military leader and statesman, as a judge and noble person, as a humanitarian fighter and servant of God, and various other aspects of his life.

Even so, has it ever occurred to us to emulate the figure of the Prophet Muhammad as a great thinker? Have we ever realized that the Prophet Muhammad in addition to being a leader and statesman, he was also 
a very great thinker? Has it ever occurred to us that the Prophet Muhammad besides being the most sincere humanitarian and servant warrior, he was also a great thinker who surpassed the greatness of all thinkers?

Has it ever occurred to us that besides being a wise judge and an excellent educator, he was actually a rational-transcendental thinker who was so good at uniting the sacred message of the sky with the profane need of the earth that it was able to bring about transformative-progressive effects: bring positive change dramatically for humanity's progress?

If we fail to see the example of the Prophet in this dimension, it is precisely this example on this dimension that Musa Asy'arie saw and voiced. For Musa Asy'arie, the Prophet Muhammad was not only an insane kamil figure that we should emulate in the aspect of a leader and educator, a husband and father, a military and statesman leader, a judge and his noble character, a humanitarian and devotee of God amazing, but also as a great thinker; as a rational-transcendental big thinker figure. When we emulate the Prophet Muhammad as this great thinker, we carry out the process of prophetic thinking; prophetic thought process: a rational transcendental thought process.

According to Musa Asy'arie, in the midst of the vacuum the spirit of thinking of Muslims today, prophetic thinking must be spoken out loud. In the midst of the sluggishness of intellectual property in most Muslims today, the exemplary prophetic thinking must be encouraged to them. In the midst of the emergence the phenomenon of people who have a high religious spirit but poor religious insight, prophetic thinking models need to be discussed in the midst of Indonesian Muslims. In the midst of the decline of Muslims in the aspects of knowledge, science and technology, again the spirit of prophetic thinking exemplifies precisely finding its actuality, relevance, and momentum to speak today.

As far as the author's observations, there are no researchers who have seriously studied Musa Asy'arie's thoughts about his epistemology of reconstruction of prophetic thinking. It must be admitted that there have indeed been a number of writings that highlight Musa Asy'arie style of thinking, but generally only portray a small part of the aspect of his prophetic thinking which includes a brief glimpse of his works.

First, Fakhrudin Faiz in his article about Musa Asy'arie's thought entitled Kebebasan Berpikir dan Revolusi Akal Budi Musa Asy'arie. In the article, Faiz described the meaning of freedom of thought that was rolled out 
by Musa Asy'arie. Faiz highlighted freedom of thought that remained dialectic with morality, spirituality and reality. Furthermore, Faiz discussed the concept of mind revolution Musa Asy'arie who was inspired by prophetic intelligence. However, Faiz did not explore the episthemology of the reconstruction of the prophetic thinking method carried out by Musa Asy'arie. ${ }^{1}$

Second, the next article was written by Zainul Abas with the title Konstruksi Filsafat Islam Musa Asy'arie: Metode Rasional-Transendental. As the title suggests, Zainul Abas explained the construction of Islamic philosophy Musa Asy'arie who used five approaches, namely historical, doctrinal, methodical, organic and teleological approaches. With a methodical approach, Zainul Abas explained that Islamic philosophy was built on the sunnah of the Prophet in thinking. The thinking method is a transcendental rational method, which analyzes empirical facts and elevates them to spiritual awareness, then builds a transcendent vision in solving a problem. Nevertheless, Abas has not discussed the epistemology of the reconstruction of the prophetic thinking method carried out by Musa Asyarie. Therefore, this paper still has significance to be explored further. ${ }^{2}$

At this point, the big question we should ask is: What is the meaning of prophetic thinking? How is the epistemology of reconstruction prophetic thinking in the perspective of Musa Asy'arie? These questions will be the common thread that forms this brief article about the epistemology of methodological reconstruction of prophetic thinking carried out by Musa Asy'arie.

\section{B. The Meaning of Prophetic Thinking Construction}

First of all, we need to briefly mention the meaning of freedom of thought before discussing the epistemological construct of prophetic thinking. This is quite important. Because Musa Asy'arie strongly emphasized freedom of thought not only conceptually in his writings alone, but also when teaching students at the Masters and Doctoral level he always encouraged all his students to think freely, openly and responsibly. Because

1 Al Makin, Mazhab Kebebasan Berpikir dan Komitmen Kemanusiaan (Yogyakarta: LESFI, 2011), p. 139-159.

${ }^{2}$ Read ibid., p. 200-218. 
one of the fundamental characters that describes the special features of humans is the quality of their thinking.

According to Musa Asy'arie, the existence that represents the essence of human beings is thinking because thinking is human excellence, and the ability to think is only possessed by humans, not possessed by other living beings. By thinking, humans can carry on scientific concepts, and with their scientific concepts, humans can shape culture and civilization. ${ }^{3}$ Therefore, thinking is basically complete freedom. There is no prohibition to think of any object in this world. There is also nothing that can forbid humans to think. ${ }^{4}$

Actually, for Musa Asy'arie, there is no need to be feared from the freedom of human thinking because freedom of thought is not the same as freedom to do where there is no freedom in action. Freedom of action is limited by the ethics and laws that apply in society. Humans may think of theft, for example, especially for a police officer who will arrest a thief, but humans cannot do an act called theft. If theft is carried out by someone, then he will be arrested for violating the ethics and laws that prohibit theft and see him as a criminal or criminal act. ${ }^{5}$

In this context, it is very interesting how Musa Asyarie describes three types of relationships between thinking and doing. First, the stage of thinking an sich, which is thinking that has not been united in action. Thinking at this stage, is a pure thought that is not related to deeds or has not become an act. At this stage, think completely free. No one can forbid it. $^{6}$

For example, pure scientists, not applied scientists, usually carried out by philosophers and scientists of pure sciences, they think of biology, physics or astronomy that have nothing to do with the reality of one's actions in social life. The theoretical errors that occur in them are not criminal and do not become objects of law. ${ }^{7}$

${ }^{3}$ Musa Asy'arie, Rekonstruksi Metodologi Berpikir Profetik (Yogyakarta: LESFI, 2016), p. 1.

${ }^{4}$ Ibid., p. 2.

${ }^{5}$ Ibid., p. 3-4.

${ }^{6}$ Ibid., p. 5.

${ }^{7}$ Musa Asy'arie, Dialektika Islam: Etos Kerja dan Kemiskinan (Yogyakarta: LESFI, 2016), p. 73. 
Second, the stage in which thinking has merged with action, and at this stage there is no freedom because there is no such thing as free action in this world. Actions that blend with thought are actions that are realized or human actions in a conscious state. Actions in conscious circumstances are always limited by ethics and law. ${ }^{8}$ For example, thinking about, planning and carrying out acts of corruption, then the act of corruption is a criminal who will get the right punishment. ${ }^{9}$

Third, actions that are not subject to ethical sanctions and legal sanctions, namely the actions of someone who has lost his thinking ability, unconscious actions, or the actions of a crazy person. ${ }^{10}$

From the relationship between the three types of typologies of thought and action, Musa Asy'arie wanted to go to the first and second levels. Pure thinking is authentic thinking that is very important for the growth and development of culture and civilization of mankind. Because authentic thinking is central to the flourishing of human creativity. This creative, authentic thinking needs to be opened freely if we want the widest possible advancement in the realm of science. Strictly speaking, he stated: Innamal afkar ummahatul a'mal, which is actually thought is the biological mother of action. ${ }^{11}$

However, because thinking is also ideally united and must bring implications to factual actions, Musa Asy'arie also emphasizes thoughts that are integrated with actions. But the activity of thinking on this second level, must be accompanied by the guidance of the conscience or qalb so as not to control lust rationality. Normatively, the Qur'an teaches people to think deeply that is united under the bright light of their qalb. Thinking that integrates with the qalb will give human ability to see the nature of the truth behind the reality of life and the reality behind an event that allows humans to stay away from damage and evil because qalb or fuâd never lie to the truth. ${ }^{12}$

Back to thinking freely, there is nothing to be afraid of thinking freely, because free thinking is free from thinking from lust which is thinking

\footnotetext{
${ }^{8}$ Asy'arie, Rekonstruksi Metodologi Berpikir Profetik, p. 5.

${ }^{9}$ Asy'arie, Dialektika Islam: Etos Kerja dan Kemiskinan, p. 73.

${ }^{10}$ Asy'arie, Rekonstruksi Metodologi Berpikir Profetik, p. 5.

11 Musa Asy'arie, Islam Keseimbangan Rasionalitas, Moralitas, dan Spiritualitas (Yogyakarta: LESFI, 2005), p. 5.

${ }^{12}$ Asy'arie, Dialektika Islam: Etos Kerja dan Kemiskinan, p. 74.
} 
controlled by the guidance of the heart. Conversely, what needs to be feared is that thinking is not free, namely thinking that is trapped in the power of lust. Thinking not free is thinking that has been controlled by lust rationality which results in anarchic, destructive and inhumane actions.

Thus, as long as thinking can walk freely from the interests of lust, thinking of looking for and finding the truth, then there is no need for fear and concern for thinking. ${ }^{13}$ "We must think as hard as we can," said Musa Asy'arie, "to the maximum extent possible to find the deepest truth, the ultimate truth, and the requirement is to be free and free from the interests and content of lust." ${ }^{14}$ Thinking which unites between akliyah reasoning and qolbiyah clear radiance is the initial meaning of prophetic thinking.

\section{Epistemology of Reconstruction of Prophetic Thinking}

Then how is the basis of epistemology and the fundamental structure of the reconstruction of prophetic thinking? Globally, the epistemology of the reconstruction of prophetic thinking presented by Musa Asy'arie originated from two groups of verses of the Qur'an, namely five verses in the first revelation in the letter al-'Alaq and two verses in the letter Ali-Imran, verses 190 and 191.

First, verses 1 to 5 in the letter al-Alaq: "Read in the name of your Lord Who Created. He has created humans from a blood clot. Read, and Lord, you are the Most Gracious, the One who teaches (man) by means of the word, He teaches man what he does not know"(QS. Al-Alaq 96: 1-5). ${ }^{15}$

In the asbāb al-nuzul discourse, there are two versions of the questions posed by the Prophet Muhammad in response to the command to read the first revelation. First, mã qara'tu, what should I read. This question is a version that says that he can read. Second, mā ana biqorī'in, I can't read. Questions from this second version state that he is illiterate, cannot read. Either the first version or the second version, what is clear is the command to read. ${ }^{16}$

\footnotetext{
${ }^{13}$ Asy'arie, Rekonstruksi Metodologi Berpikir Profetik, p. 106.

${ }^{14}$ Ibid.

${ }^{15}$ Asy'arie, Dialektika Islam: Etos Kerja dan Kemiskinan, p. 64.

${ }^{16}$ Asy'arie, Rekonstruksi Metodologi Berpikir Profetik, p. 49.; Compare also
} with Ibn Jarīr Al-Ṭabarī, Jamī' al-Bayān 'an Ta 'wīlatil Qur'ān (Kairo: Dār al Ibn Jauzī, 2008), Juz 27, p. 562-564. 
According to Musa Asya'rie, the story of the descent of the five verses in the first revelation is actually very important in terms of looking for exemplary thinking, and very clearly the Prophet has practiced exemplary thinking very intelligently. This is because the Prophet with his fatanah character is having a very high intelligence. ${ }^{17}$ At that time, the Prophet Muhammad did not only carry out textual readings, but more than that he also did a reading on the social dynamics of the life of the people.

At that time, the Prophet Muhammad witnessed the social life of his people already trapped in the behavior of massive moral decadence. Massive moral decadence includes gambling, drunkenness, robbery and violent conflict between ethnic groups, the practice of the ribawi economic system, worshiping power and worshiping idols and having the heart to commit murder of their own daughters for fear of poverty that befalls them.

Witnessing the phenomenon of moral decadence that is so massive and has touched all aspects of the social life of its people, he is anxious and asks introspective-critical questions: Why does massive moral decadence afflict the social life of this 7 th century Arab society? From the results of a critical reading of the dynamics of the social life of the community, it turns out that the Prophet found a root problem that was called by Musa Asy'arie as material theology or we can say materialistic theology. What is meant by material theology?

"A theology that respects and worships human creation itself. A theology that emphasizes the ideology that was initiated by humans for the sake of power and wealth. An ideology that emphasizes money and makes money the purpose of life. A material ideology that makes a person ready to die to get it, in the form of power and money", wrote Musa Asy'arie. ${ }^{18}$

This is the theology of material misguided as well as misleading which is the basis of the destruction of society's moral at the time, but instead became the community's divine system.

The Prophet Muhammad truly realized that if the divine system adopted by a society, as a fundamental system in the life of society is wrong and deviant, then the result would be to produce wrong and deviant actions, as reflected in anarchic social reality, destructive and immoral to the Arab community in Mecca at that time. Therefore, to improve the condition of the Arab community at that time known as the Jahiliah Arab community,

${ }^{17}$ Asy'arie, Dialektika Islam: Etos Kerja dan Kemiskinan, p. 65.

${ }^{18}$ Asy'arie, Rekonstruksi Metodologi Berpikir Profetik, p. 52. 
there was no other way except to change the system of theology or belief system of God.

The wrong and deviant divinity system is a divine system that worships human creation itself, such as worshiping statues, idols and human-made ideologies as a symbol of deifying money, power and science and technology. The Prophet changed it with a straight and not deviant divinity system, namely the monotheistic deity system which only emphasized the Almighty God, who created mankind and who set the schedule of death and guaranteed his life in this world, which became the beginning and end of all that exists and only God is the Almighty and the Most Determining. ${ }^{19}$

Thus, in the view of Musa Asy'arie, the Prophet Muhammad actually taught the sunnah of the Prophet in thinking, namely the practice of thinking to understand the reality behind events, capturing the meaning behind all that exists with thinking methods: iqro' bismi robbika al-ladzi kholaq, namely reading with the spirit calling the name of your Lord who created. ${ }^{20}$

Thus the readings made by the Prophet Muhammad did not stop only as a literal reading, but critical social readings in revealing the meaning behind the social reality of the deviant society to later carry out a radical transformation by changing the theological system. This is a smart reading.

"The reading of the Prophet Muhammad is intelligent," said Musa Asy'arie, "reaching strategic choices not reading letters but reading the reality of society, not eradicating illiteracy, but changing the theological system, from the position of humans to their creation, changed to deify God who created it alone ". 21

In the perspective of Musa Asy'arie, the Prophet's reading of the social reality of the Jahiliyah Arab community also used two types of struggle strategies, namely cultural strategies in the context of Mecca and structural strategies in the context of Medina. With the cultural strategy in Medina, the Prophet preached the need for people to abandon material theology that had made them fall into violent conflict. Material theology that makes people fall in dignity of humanity. Material theology that has made previous nations

\footnotetext{
${ }^{19}$ Asy'arie, Dialektika Islam: Etos Kerja dan Kemiskinan, p. 67.

${ }^{20}$ Ibid., p. 67-68.

${ }^{21}$ Ibid., p. 71.
} 
strong in their livelihoods fall. Human civilization also experienced total destruction and made a nation extinct. ${ }^{22}$

Furthermore, in the strategy in the Medina period, the struggle of the Prophet Muhammad was directed at the structural changes in people's lives. Structural changes begin with structuring power structures based on morality and integrity. Nevertheless, the structural changes designed by him in the Medina period remained based on cultural change. How can a power be exercised to maintain the harmony of social life which is then confirmed in the principle of deliberation. ${ }^{23}$

Interestingly enough, from the reading of the social dynamics carried out by the Prophet Muhammad by finding material theology as the root of the problem, Musa Asy'arie carried out social-contextual readings on the phenomena of contemporary society. From the contextual reading, it turns out that the phenomenon of material theology in the form of ideological concepts in social systems, political systems, cultural systems, legal systems, and religious systems that are materially based still has a strong influence in the lives of modern society today. ${ }^{24}$

According to Musa Asy'arie, social phenomena today also show human tendency to affirm their own creations, such as making money, power, ideology, and increasingly sophisticated technology. Everyone is looking for, pursuing and accumulating as much money as possible by all means, because everything requires money, be all the money, become the purpose of his life, to fight for someone who sacrifices his pride, even his life.

Likewise with power, because power can regulate everything, so that money and power are like two sides of a coin, both of which are unitary. Money to buy and get power and power to regulate the acquisition of money. Who gets what and how it is a matter of power.

Power and money eventually require an ideology that is expected to influence and shape public opinion in the interests of accumulating money and the power of elites so that the interests of the elite can be accepted by the public and the public wants to support and safeguard their interests with ideological manipulation. Finally they also needed technology

\footnotetext{
${ }^{22}$ Asy'arie, Rekonstruksi Metodologi Berpikir Profetik, p. 53-54.

${ }^{23}$ Ibid., p. 56.

${ }^{24}$ Ibid., p. 52.
} 
to engineer ideology so that the public finally formed its opinion for the interests of its elites. ${ }^{25}$

Thus by contextualizing the Prophet's intelligent reading of the social dynamics of contemporary society's life, Musa Asy'arie not only talked about the intelligent reading of the Prophet theoretically, but he also emulated the method of reading the intelligent Supreme Court directly. The Prophet's intelligent reading is not only conceptually explored, but also used by him in fact to uncover fundamental-actual problems that are in the midst of 21 first century society.

Even beyond all that, for Musa Asy'arie, the smart solution presented by the Prophet to the 7th century people at that time must also be actualized towards society today. With contextual reading, for Musa Asy'arie contemporary society must change its mindset so as not to make money and power, ideology and technology a goal in itself, but as a vehicle of virtue as well as dedication to God and humanity.

With these contextual readings, Musa Asy'arie also recommended that contemporary societies need to change their orientation: from orientation to luxury and power only, towards orientation to the pleasure of God and the benefit of humanity. From the orientation of economic benefits and worldly pleasures to the direction of divine orientation and here after. By changing this mindset and orientation, contemporary societies that are trapped in material theology can release themselves by holding authentic theology: divinity theology, monotheistic theology.

From the various arguments above, it is clear that the stressing point of reading the Prophet lies in its social dimension. But Musa Asy'arie also pointed out that in the first revelation, there was a very clear signal to develop scientific discourse in the broadest sense according to the scope of meaning contained in the term iqra'.

Therefore, let's look at the meaning of the verse extensively through the interpretation perspective. The word iqra' which comes from the word qara'a in the beginning means to gather. In Arabic dictionaries, iqra' contains several meanings: conveying, studying, reading, deepening, researching, knowing its characteristics, and so on, all of which can be returned to the essence of" gathering "which is the root meaning of the word. Because the first verse is commanded: Read it!, the question: What should

${ }^{25}$ Asy'arie, Dialektika Islam: Etos Kerja dan Kemiskinan, p. 69-70. 
be read? Uniquely the first verse above does not mention any object that must be read.

In the interpretation perspective, there is a linguistic rule which states that if a verb requires an object but no object is mentioned, then the object in question is general in nature, including everything that can be reached by the word. From this, it can be concluded that because the word iqra 'is used in the sense of reading, studying, conveying, studying, and researching, and because the object is general, the object of the word includes everything that is affordable, whether it is holy reading from God or not, whether it involves written or unwritten verses. As a result the iqra' command includes studies of the universe, society and oneself, as well as written readings, whether holy or not. ${ }^{26}$

At this point, if we classify objects reading, examining, researching, and studying through philosophical perspectives of science or integrative approaches, then globally reading objects cover three aspects: empirical phenomena that are the object of scientific studies, social phenomena and rational asbestos which become sociological studies and philosophy, as well as supra-rational abstract phenomena which are the object of the study of Sufism, mysticism or religious discourse. ${ }^{27}$ The study, scientific research and reading of the three regions of the object globally will produce three major clusters of scientific typologies:

(1) Scientific study of the verses of kauniyah will produce natural sciences, natural sciences in the broadest scope covering biology, physics, chemistry, mathematics, and others.

(2) Human verses that will produce social and philosophical sciences which include sociology, psychology, history, anthropology, philosophy, language, literature, art and others;

(3) Divine verses or qur'āniyah which will produce religious sciences which cover ulum al-Qur'ān and hadith, interpretations, uṣul fiqh and jurisprudence, theology and mysticism, as well as various other religious sciences.

${ }^{26}$ M. Quraish Shihab, Tafsir Al-Mishbah, vol. 15 (Jakarta: Lentera Hati, 2002), p. 393.

${ }^{27}$ M. Amin Abdullah, Islamic Studies di Perguruan Tinggi (Yogyakarta: Pustaka Pelajar, 2006), p. 101-111; and also see Zainal Abidin Bagir, ed., Integrasi Ilmu dan Agama (Bandung: Mizan, 2005), p. 241-253. 
The structure of prophetic reading in this first part, we can draw it in the form of the following sketch:

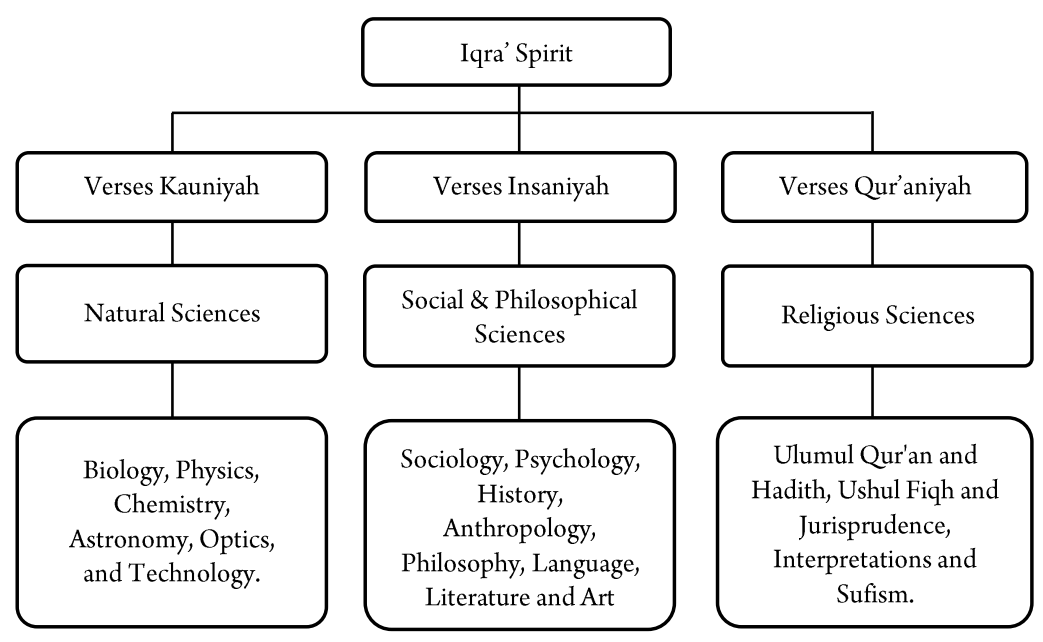

Figure 1. Structure of Prophetic Reading

From the explanation above, we understand that the peak of idealism desired by the 5 verses in the first revelation is scientific reading by using our faculty of reason to the fullest to produce knowledge in the broadest sense in a comprehensive manner. In this context, it is also reasonable if Musa Asy'arie through the first 5 verses emphasizes that the most important and most significant example that we must take from the figure of a Prophet Muhammad is the example of his rational-transcendental thinking.

Because historically-sociological, the sacred command to read through the first 5 verses is done by the angel Jibril to the Prophet Muhammad directly, face to face. And the Prophet Muhammad with his holy faculty of reason, has carried out a process of reading and thinking rationally-transcendental towards the social life of 7 th century Arab society.

A reading and thinking that is transformative-progressive, which results in radical changes that are getting better in terms of beliefs, mindset, attitudes and behavior of the people at that time. Of the people who worship idols become mere worshipers of God. From the attitude of blind fanaticism to ethnicity, the people who prioritize the truth. From the primordialism mindset, which assesses glory and appreciation must be based on tribal and hereditary factors, changing to the professional mindset that glory and appreciation must be based on one's charity and achievements. 
From people who do not like to read, become a society that loves science. From the people who have never used their minds to think rationally transcendental, they have transformed into people who always meditate, think, and reflect on the universe and facts of life, so that they become inspirators of civilization that ignite the torch of enlightenment for mankind.

Now let's enter the second structure. In the second structure, Musa Asy'arie revealed two verses in the letter Ali-Imran verses 190-191 as the basis of his epistemology.

"Indeed, in the creation of heaven and earth, and alternating nights and days there are signs for those who have reason, (ie) those who remember Allah while standing or sitting or lying down and thinking about the creation of heaven and earth (while saying): "Our Lord, You have not created this in vain, Glory to You, so keep us from tormenting hell" (Surat Ali-Imran 3: 190-191). ${ }^{28}$

The two verses above provide a clear message that the combination of remembrance and thought, should not only stop at the divine awareness of the creation of the universe and all its contents. The combination of remembrance and thought not only stops the transcendental awareness that the entire universe and its contents are created by the Supreme, All-Powerful, and Wise. The ideal estuary to be addressed by these two verses is that the combination of the sanctity of remembrance and the power of thought in an ulul albāb must be able to reveal the diversity of secrets, mysteries, puzzles, and universe laws and their contents which produce products of knowledge in various forms as broad as possible.

This is what Musa Asyarie wanted when making these two verses as the main foundation for his epistemological construction of prophetic thinking. Let's look at the argument. According to Musa Asy'arie, in verse 190 in the letter Ali Imran explained that the object of thinking for people who are intelligent or ulul albāb is the creation of the heavens and the earth as they are. Thinking at this stage includes:

1) Thinking about the process of discovering God's laws in it, a sunnatullah, the mechanism of natural law and all and;

${ }^{28}$ Asy'arie, Rekonstruksi Metodologi Berpikir Profetik, p. 89. 
2) Thinking of what exists as an ingredient needed for human life, starting from food, as well as the potential contained in it for the survival of humans as a whole. ${ }^{29}$

Furthermore, in the next 191 verse, it is explained about the process of thinking through four stages: first, remembering the power of God in any situation as a starting point in thinking. By always remembering the power of God in thinking, it will save his mind from falling into the power of lust or pragmatic power interests. Humans can think freely and authentically to find the truth itself, not to legitimize their interests, both ideological and power interests.

This first stage, the remembrance stage which is represented by the phrase "yażkurullahh", namely in the form of theological awareness or transcendental awareness as the starting point of a scholar and scientist before exploring various objects of science that are on the face of the universe and its contents. With this transcendental awareness, an ulul albāb will experience peace of mind so that it makes the mind clear, bright and ready to receive divine guidance. ${ }^{30}$

The second stage of thinking, namely thinking about the creation of the heavens and the earth as they are. Thinking about the creation of the heavens and the earth as they are is thinking in the process of creation, to find the mechanism in it. Thinking to find out how the process of the universe works in a systemic mechanism. Thinking about this process will give birth to the concepts of science and technology which in its development are crucial for the progress of civilization and human culture.

This second stage, the stage of thinking represented by the sentence "yatafakkarūn." But thinking in the context of this verse, not thinking carelessly or reflecting that is general in nature. The idealism intended by the verse is to think methodologically and scientifically in order to find the laws of God that can produce knowledge, science and technology in the broadest sense. When a scientist studies and examines the verses of kauniyah, he uses the method of tajribī, observation and experimentation with all scientific instruments so that scientific laws can be found.

When a scientist observes and conducts research on social phenomena, he applies the burhani method, discursive-demonstrative

${ }^{29}$ Ibid., p. 89-90.

${ }^{30}$ M. Quraish Shihab, Tafsir Al-Mishbah, Vol. 2 (Jakarta: Lentera Hati, 2002), p. 295. 
method in order to produce a variety of knowledge that is in accordance with the social object. When a scholar conducts a study of Quranic verses or religious phenomena, he can no longer just apply the method of tajribi and burhani alone; He also needs to complete it with the Irfani method with his intuition faculty. So, in the desired stage of thinking in the verse, the methodology of science is patterned which is combining the three scientific methods that are experimentation, demonstration, and intuition. ${ }^{31}$

This first and second stage, as a framework for building epistemology or the fundamental structure of prophetic thinking methodology initiated by Musa Asyarie.

The third stage is thinking that is based on an awareness of the power of God that will give birth to transcendental consciousness, which gives direction to what all the processes of human thought with the advancement of science and technology concepts are carried out. Thus, it is expected that the impact of human thought does not result in the occurrence of evil and damage to human life itself. In contrast, science and technology become humanitarian service to distance human beings from the torments of hell or from the destruction and suffering of mankind.

In this third stage, there is a process of transcendence of knowledge, science and technology in the ulul albāb. The process of transcendence occurs when ulul albāb sees and realizes the destructive impact of the application of the concepts of science and technology in human life. Because of that, ulul albāb tried to sensitize its users to form a common prosperity. ${ }^{32}$

In other words, in this third stage, teleological spiritual awareness is present again: that all results in the form of knowledge, science and technology must have a moral-spiritual compass that is for goodness, prosperity, comfort, ease, peace, and happiness of mankind. This third stage is expressed in the following verse in the form of a prayer: "robbana mā kholaqta hãża bātila".

Therefore, prophetic thinking is always based on an awareness of faith in God's absolute power, and simultaneously relates limited human power. Thus, we will enter the fourth stage, namely worship as the culmination of human thought where the progress of science and

${ }^{31}$ Muhammad Abid Al-Jabirī, Taqwīn al-Aql al- 'Arabī (Beirut: Markaz Dirāsat al-Wuhdah al-'Arabiyah, 1989), p. 75-328.

${ }^{32}$ Asy'arie, Dialektika Islam: Etos Kerja dan Kemiskinan, p. 80. 
technology is not used for human damage and suffering, but for the good and usefulness of life together. Science and technology are an extension of God's own verses, and become a way for humans to devote themselves to God and humanity. All God's creations are not vanity and humans must stay away from their vanity, live without meaning and wallow in $\sin .^{33}$

In this fourth stage, is the stage of worship or service. An ulul albāb will stay away from the destructive effects of the application of knowledge, science and technology in human life, because it will make itself threatened by the torment of hell in the hereafter. For this reason, an ulul albāb always carries the intention of worship, that all forms of progress in the fields of knowledge, science and technology are a form of devotion to a scientist to the Creator. This last stage, hinted at in the verse fragment: "subhānaka faqinā 'ażābannār".

This third and fourth stage illustrates the implications of prophetic thinking to build a civilization that can bring humanity prosperity, peace and happiness universally. We can see the stages of ulul albāb prophetic thinking in the following chart:

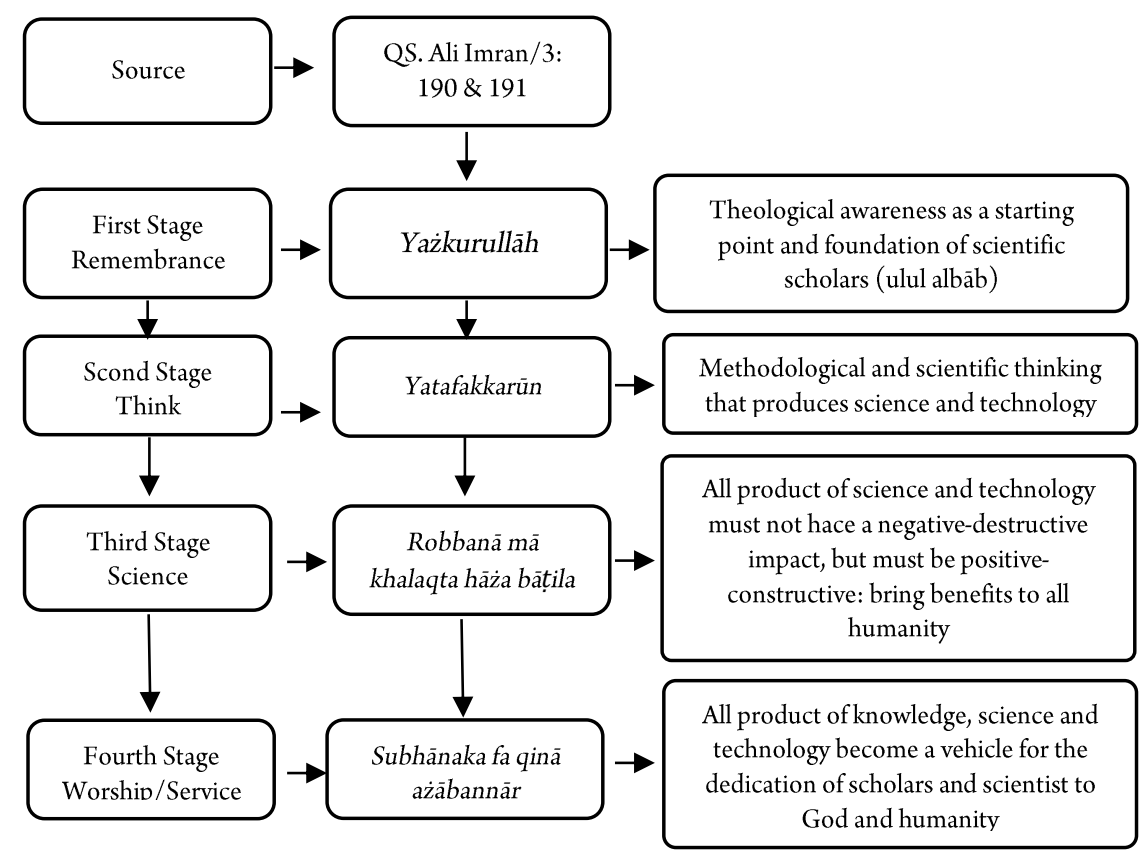

Figure 2. Stages of Ulul Albāb Prophetic Thingking

${ }^{33}$ Ibid., p.90-92. 
That is the message that is desired in the two verses of the second group on the Ali-Imran letter which is scientific-knowledge which must be possessed by the ulul albāb, scientists and scholars. These stages in the thinking process are what Musa Asy'arie calls prophetic thinking. People who are able to apply this process of prophetic thinking are called ulul albāb.

Here, we need to investigate further: who is actually called ulul $a l b a \bar{b}$ ? The word $a l b a \bar{b} b$ is the plural of lub which means the essence of something. In Mu'jam Mufrodāt al-Alfäż al-Qur'ān, al-Raghib al-Aṣfahanī, defines lub with a clear and pure mind of various forms of shortcomings and defects. So named, because $l u b$ is a part of a clear and pure human. $L u b$ is a form of clear, pure, clean, even holy mind; huwa mā zakā minal 'aqli.

For this reason, then God named like that connected the phenomena of the laws of life in their broadest meaning to ulul albāb. Because only people who have clear and clean minds are called ulul albāb, who are able to know, understand, and at the same time reveal the laws that God has placed on the face of the universe and their contents. ${ }^{34}$

From the above meanings, we see that ulul albāb is not an arbitrary person, not an average person. We can say that ulul albāb are intellectuals, and scientists who are able to read, understand, research, study and explore the phenomena of the universe along with everything in human life with various methods that are in accordance with their objects while formulating them into various forms of knowledge, science and even technology are in accordance with their respective competencies accompanied by humandivine awareness.

In reading universe phenomena, intellectuals, or scientists need to depart from divine awareness but must lead to humanity. All activities of reading, observation and research carried out by a scholar and scientist must be based on a Divine consciousness. But don't forget, that the fruits of observation and research in the form of knowledge, science, and technology must have an impact on human welfare, comfort, convenience, prosperity and happiness. Vertical awareness of scholars and scientists must have a positive impact on the horizontal realm of humanity by producing knowledge, science and technology that must bring benefit to universal humanity.

${ }^{34}$ Al-Ashfahani Al-Raghib, Mu'jam Mufrodat Alfādz al-Qur'ān (Libanon: Dār al-Kutub al-Ilmiyah, 2008), p. 500. 
Why do you have to bring universal benefits? "Humanly", stated Musa Asy'arie, "science and technology actually belong to all humans and to humans all, not private property or a group of people. Science and technology are also not to destroy life together. Therefore, the mastery of science and technology by a handful of people and only for their own interests is actually contrary to the values contained in science and technology itself." ${ }^{135}$ But more than that, science and technology are not only for the universal good of mankind, but also must create harmony between humans themselves with the universe:

"Science and technology are manifestations of the aesthetics of human culture to create harmony and preservation of the universe and the surrounding environment. The form of culture of science and technology is the manifestation of human intellectual anxiety towards the challenges facing life. Science and technology are human solutions to universal humanitarian problems, becoming efforts to improve better and more prosperous living together. The way out that has an axiological dimension in the balance of life is maintained in the underlying values, "writes Musa Asy'arie. ${ }^{36}$

We can draw the structure of prophetic reading in the second part in the following sketch:

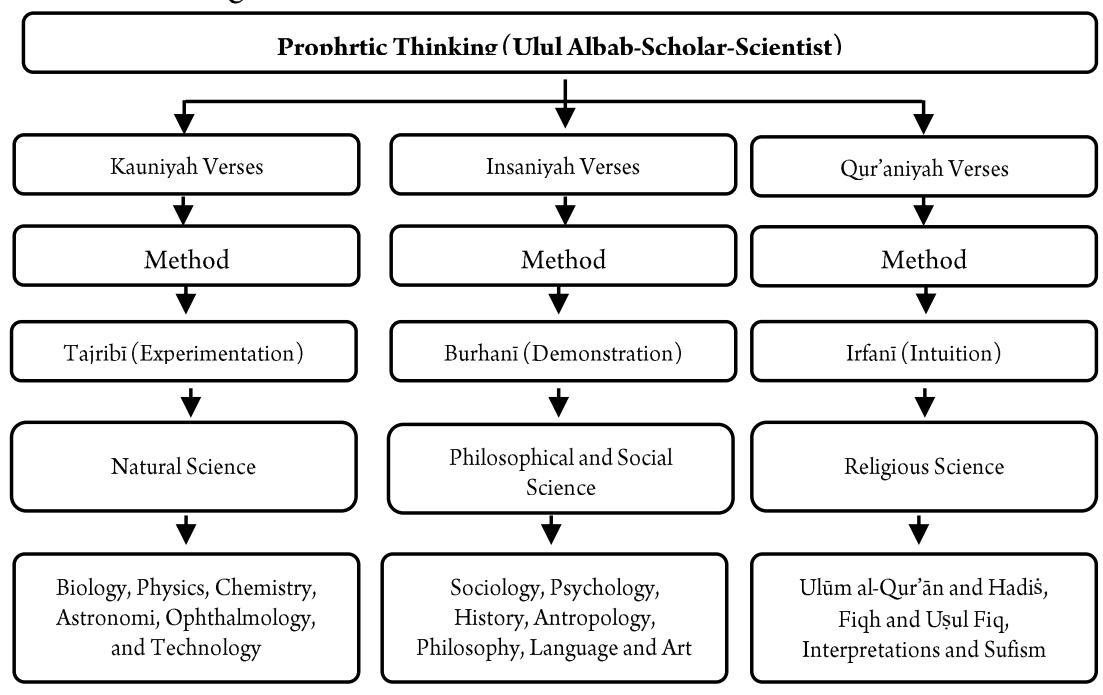

Figure 3. Structure of Prophetic Reading

${ }^{35}$ Musa Asy'arie, Filsafat Ilmu: Integrasi dan Transendensi (Yogyakarta: LESFI, 2016), p. 51.

${ }^{36}$ Ibid., p.91. 
This combination of the two fundamental structures of reading between the first and the second is called by Musa Asy'arie as the methodology of prophetic thinking. A transcendental rational method of prophetic thinking. What exactly is meant by transcendental rational thinking?

"Thinking in the prophetic method", writes Musa Asy'arie, "actually is rational transcendental thinking. The rationality lies in mastering the creation process that starts from building concepts, then followed by consistent trials and then formulated and written in science and technology theories that are accurate and applicable. Meanwhile, transcendental lies in the recognition of his faith in dynamic and melting verbs for the benefit of human life, not for the benefit of human selfishness, sectoral egoism which tends to divide in the interests of political power and pragmatism. ${ }^{137}$

At this point, we also need to take a moment to look at the two groups of verses above which are comparative structures of prophetic thinking. In the first group of verses in Al-Alaq verse 1-5, the actual audience addressed by the verse is general. Although in the context of the descent of the verse in the form of an order to read directly to the Prophet Muhammad, the purpose of the message is general: to all Muslims, even to all humanity. Here, the rules of uṣul fiqh apply: al-'ibrah bi 'umūmi al-lafżi là bikhusūṣi $s a b a b$, "The moral message that is used as a handle is the general form of the sentence, not the context of the specific descent of the verse". ${ }^{38}$

Because the message conveyed is general for all humanity, it is only natural that in groups of verses the first revelation does not explicitly mention scientific methodology in reading the universe and its contents. In general, we frame the meaning of "reading" in groups of verses as understanding, studying, and examining the universe that will produce various forms of science, both natural sciences, social sciences, and religious sciences, and the phenomena of human life.

Of course, readings that are capable of producing various kinds of knowledge require a methodology that is suitable for each scientific object.

${ }^{37}$ Asy'arie, Rekonstruksi Metodologi Berpikir Profetik, p. 95; Compare also with Musa Asy'arie, Filsafat Islam, Sunnah Nabi Dalam Berpikir (Yogyakarta: LESFI, 2002), p. 7-8.

${ }^{38}$ Look inside M. Quraish Shihab, Membumikan Al-Qur'an (Bandung: Mizan, 1997), p. 89. 
However, in this verse there is no mention of the cues of scientific methodology. Even though once again, we can still read it openly and completely by presenting the scientific methodology.

This is different from the second group of verses in the letter AliImran verses 190-191. In both verses, in the first verse (verse 190), God has explicitly referred to the figure of ulul albāb, intellectuals and scientists who are clear in their minds and hearts. In this verse, there is an affirmation at the beginning by using the word "inna" as ta'id, affirmation. Then at the end of the verse it is reaffirmed with "lam" which is included in the word ayat laayatin. The letter "lam" (J) in the word "la'âyātin" is the khobar of "inna" which aims to increase the affirmation of the meaning in the verse (ziyādah ta'kid). ${ }^{39}$

What does all this mean? With the creation of the heavens and the earth along with their contents, and the alternation of rounds of night and day, God wants all of His creations as phenomena, verses, and signs for ulul albāb, namely scholars and scientists who have hearts and minds that are pure, clean and bright, which must be read, understood, studied, researched, and disclosed by its laws.

With what reveals God's laws on the face of the universe and its contents? The next verse, verse 191 is what explains the method: that is by combining the dhikr and thought together. As we have explored before, this combination of remembrance and thought is a scientifically structured scientific methodology. The methodological aspects are very emphasized in the two verses in the letter Ali-Imran. The thinking process that is scientific methodological is systemic integrative which is a unit that is not separate from one element to another. That is the epistemology of the methodology of prophetic thinking reconstruction initiated by Musa Asyarie.

\section{Conclusion}

From the various explanations above, it is very appropriate if Musa Asy'arie asserted that the most important example for us to emulate from the Prophet Muhammad, especially for the academic community, intellectuals, scholars and scientists, is exemplary in prophetic thinking, exemplary

${ }^{39}$ Muhammad Ali Al-Ṣabuni, Șafwatu al-Tafāsir, vol. Juz-1 (Kairo: Dār alHadis, 2001), p. 248. 
thinking rationally transcendental. That is the prophetic message voiced by Musa Asy'arie and we need to hear his voice. We need to welcome his appeal with an open mindset. Especially nowadays, until entering the 3rd millennium today, almost the majority of Muslim nations are at the lowest level in the aspects of science, science and technology development. The majority of Muslims today are still far behind in the aspects of science, science and technology compared to other nations.

Most Muslim nations are still far behind in science and technology compared to Northern Europe, North America, Australia and New Zealand who are Protestants. The majority of Muslim nations are still inferior to science and technology with Eastern Europeans who are Catholics, and Israelis who are Jewish. Even the majority of Muslim nations are still very weak and defeated compared to Indians who are Hindus, Chinese, South Koreans, Taiwanese, Hong Kong, and Singapore who are Buddhist Confucianism, as well as with Japanese Buddhists and Buddhist Thais.

Though one of the absolute conditions for a nation to be the front guard in the construction of a noble civilization is to master knowledge, science, and technology, in addition to having strong beliefs and noble character as the social ethics of people's lives. In other words, we will never be able to be an example of civilization for other nations if we do not master the main key, namely knowledge, science and technology.

At this crucial point, one of the main prerequisites for achieving progress in knowledge, science, and technology is changing our mindset. That is why, today, our priority in emulating the Prophet Muhammad is in the aspect of his fatonah, in his faculty of prophetic intelligence, without denying the dimensions of șidiq, amanah and tabligh. Today, now and here, we must bring back the dimension of fathonah to the Prophet by applying the prophetic thinking paradigm in the midst of our lives.

Because with this prophetic intelligence, we can apply thinking methodologically that are able to understand the truth in various stages in a holistic and integrative manner. Because with this prophetic thinking, we will be able to integrate between the verses of kauniyah, insaniyah, and quraniyah in the figure of an intellectual, scholar, and scientist in fact in real action for the good, welfare, peace and happiness of living with humanity.

Because with this paradigm of prophetic thinking, the results of the achievements of knowledge, science, and technology can manifest the blessings of goodness for the life of the universe. Because the ulul albāb is no 
longer controlled by lust, its own narrow interests, and its sectoral ego, but its reason has been guided by its clear and clean heart light which can unite the sacred message of heaven and earth; Who is able to unite the sacred message of God with the universal needs of humanity. [.]

\section{References:}

Abdullah, M. Amin. Islamic Studies di Perguruan Tinggi. Yogyakarta: Pustaka Pelajar, 2006.

Al-Jabirī, Muhammad Abid. Taqwīn al-Aql al-'Arabī. Beirut: Markaz Dirāsat al-Wuhdah al-'Arabiyah, 1989.

Al-Raghib, Al-Ashfahani. Mu'jam Mufrodat Alfādz al-Qur'ān. Libanon: Dār al-Kutub al-Ilmiyah, 2008.

Al-Ṣabuni, Muhammad Ali. Șafwatu al-Tafāsir. Vol. Juz-1. Kairo: Dār alHadis, 2001.

Al-Ṭabarī, Ibn Jarīr. Jamī’ al-Bayān 'an Ta’wīlatil Qurāan. Kairo: Dār al Ibn Jauzī, 2008.

Asy'arie, Musa. Dialektika Islam: Etos Kerja dan Kemiskinan. Yogyakarta: LESFI, 2016.

Asy'arie, Musa. Filsafat Ilmu: Integrasi dan Transendensi. Yogyakarta: LESFI, 2016.

Asy'arie, Musa. Filsafat Islam, Sunnah Nabi Dalam Berpikir. Yogyakarta: LESFI, 2002.

Asy'arie, Musa. Islam Keseimbangan Rasionalitas, Moralitas, dan Spiritualitas. Yogyakarta: LESFI, 2005.

Asy'arie, Musa. Rekonstruksi Metodologi Berpikir Profetik. Yogyakarta: LESFI, 2016.

Bagir, Zainal Abidin, ed. Integrasi Ilmu dan Agama. Bandung: Mizan, 2005.

Makin, Al. Mazhab Kebebasan Berpikir dan Komitmen Kemanusiaan. Yogyakarta: LESFI, 2011. 
Zaprulkhan

Shihab, M. Quraish. Membumikan Al-Quran. Bandung: Mizan, 1997.

———. Tafsir Al-Mishbah. Vol. 15. Jakarta: Lentera Hati, 2002.

_-_. Tafsir Al-Mishbah. Vol. Vol. 2. Jakarta: Lentera Hati, 2002. 